\title{
Unusual treatment for calcifying odontogenic cyst using decompression tube to
}

\section{prevent pathological fracture}

Tratamento incomum para cisto odontogênico calcificadlo usando tubo de descompressão para evitar fratura patológica

Tratamiento inusual para la calcificación del quiste odontogénico mediante el uso de un tubo de descompresión para prevenir fracturas patológicas

Received: 01/08/2021 | Reviewed: 01/13/2021 | Accept: 01/17/2021 | Published: 01/20/2021

Natália Barbosa de Siqueira ORCID: https://orcid.org/0000-0003-0245-3639 São Paulo State University, Brazil E-mail: natalia_siqueira_@hotmail.com João Roberto Trindade Costa Filho ORCID: https://orcid.org/0000-0002-2664-0116 Private Clinic, Brazil E-mail: joaoroberto19@hotmail.com

João Victor Soares Rodrigues ORCID: https://orcid.org/0000-0002-1812-2589 São Paulo State University, Brazil E-mail: joao.vic.t@hotmail.com

Eduardo Hochuli-Vieira ORCID: https://orcid.org/0000-0003-4040-9313 São Paulo State University, Brazil E-mail: hochuli@me.com

Roberta Okamoto

ORCID: https://orcid.org/0000-0002-6773-6966 São Paulo State University, Brazil E-mail: beta.okamoto@gmail.com

Belmiro Cavalcanti do Egito Vasconcelos ORCID: https://orcid.org/0000-0002-6515-1489 University of Pernambuco, Brazil

E-mail: belmirovasconcelos@gmailcom

\begin{abstract}
The calcifying odontogenic cyst (COC) is an uncommon lesion, with variable clinical and histopathological behavior. The cystic form is the most frequent and the most common histological characteristic is the presence of a variable number of phantom cells in the epithelial component. The standard treatment for this injury is enucleation followed by curettage or excision. However, when other factors are associated, this single-step approach can lead to complications such as pathological fractures. A common treatment for keratocysts and dentigerous cysts, but uncommon for COC has been showing high effectiveness. Thus, a two-stage approach using a tubular object to perform initial decompression of the lesion and later excision of the lesion can be performed in order to prevent complications. Here we report a twostage treatment, through initial surgical decompression, of a COC associated with a lower second molar in the mandibular basilar region, using a tubular device, in which a pathological fracture was prevented. The results of this case corroborate the use of decompression applied to the treatment of COC.
\end{abstract}

Keywords: Odontogenic tumors; Calcifying odontogenic cyst; Pathology oral.

\section{Resumo}

O cisto odontogênico calcificante (COC) é uma lesão incomum, com comportamento clínico e histopatológico variável. A forma cística é a mais frequente e a característica histológica mais comum é a presença de número variável de células fantasmas no componente epitelial. O tratamento padrão para essa lesão é a enucleação seguida de curetagem ou excisão. No entanto, quando outros fatores estão associados, essa abordagem em uma única etapa pode levar a complicações, como fraturas patológicas. Um tratamento comum para ceratocistos e cistos dentígeros, mas incomum para COC, tem mostrado alta eficácia. Assim, uma abordagem em dois estágios utilizando um objeto tubular para realizar a descompressão inicial da lesão e posterior excisão da lesão pode ser realizada a fim de prevenir complicações. Relatamos aqui o tratamento em dois estágios, por meio da descompressão cirúrgica inicial, de um COC associado a um segundo molar inferior na região basilar mandibular, por meio de um dispositivo tubular, no qual foi evitada uma fratura patológica. Os resultados deste caso corroboram o uso da descompressão aplicada ao tratamento do COC. 
Palavras-chave: Tumores odontogênicos; Cisto odontogênico calcificante; Patologia oral.

\section{Resumen}

El quiste odontogénico calcificante (QOC) es una lesión infrecuente, con comportamiento clínico e histopatológico variable. La forma quística es la más frecuente y la característica histológica más común es la presencia de un número variable de células fantasma en el componente epitelial. El tratamiento estándar para esta lesión es la enucleación seguida de legrado o escisión. Sin embargo, cuando se asocian otros factores, este enfoque de un solo paso puede dar lugar a complicaciones como fracturas patológicas. Un tratamiento común para los queratoquistes y los quistes dentígeros, pero poco común para los AOC, ha mostrado una alta efectividad. Por lo tanto, se puede realizar un abordaje en dos etapas utilizando un objeto tubular para realizar la descompresión inicial de la lesión y la escisión posterior de la lesión con el fin de prevenir complicaciones. A continuación presentamos un tratamiento en dos etapas, mediante descompresión quirúrgica inicial, de un AOC asociado a un segundo molar inferior en la región basilar mandibular, mediante un dispositivo tubular, en el que se evitó una fractura patológica. Los resultados de este caso corroboran el uso de la descompresión aplicada al tratamiento de los AOC.

Palabras clave: Tumores odontogénicos; Quiste odontogénico calcificante; Patología oral.

\section{Introduction}

Calcifying Odontogenic Cyst (COC) is a rare odontogenic lesion (Yong et al., 199), first reported as a separate entity in 1962 by Gorlin (Gorlin et al., 1962). The World Health Organization has defined it as a cystic lesion covered by ameloblastomatous epithelium, containing focal accumulations of ghost cells (El-Nagar et al., 2017).

COC corresponds to 1-3\% of all odontogenic cysts and tumors (Jaeger et al., 2017), has no predilection for gender or age (Toida, 1998) and has a similar occurrence in the mandible and maxilla, with the canine region being the most affected when compared to other regions (De Arruda et al., 2018). It is usually central, that is, intraosseous, and peripheral variants, which occur in the gingiva and alveolar mucosa, may occur. Generally, occurrence is central, or intraosseous, occurring peripheral variants which occur in the gums or buccal mucosa (Jonhson et al., 1997).

Radiographically, they may exhibit uni or multilocular radiolucent areas, with variable margins, from well-defined to poorly defined, with the presence of radiopaque foci with varying densities and sizes in their interior (Gorlin et al., 1962, Buchener, 1991, Neville et al., 2016). The presence of impacted teeth and root resorption are also found frequently (Gorlin et al., 1962, Yoshiura et al., 1998, Neville, 2016).

The therapeutic modalities indicated for the treatment of COC involve simple enucleation and curettage in a single stage, regardless of the variant (Buchener, 1991, Ledesma-Montes et al., 2008). However, when anatomical structures can be compromised, pathological fractures or even mutilation of the patient in cases of large injuries may occur as a result of these surgical modalities, other forms must be considered. Thus, therapeutic resources in two stages, with the decompression or marsupialization, followed by enucleation may be used (Emam et al., 2017). Other odontogenic cysts have been treated by marsupialization or decompression efficiently (Pogrel et al., 2004, Martínez-Pérez et al., 2001, Seintou et al., 2014). The treatment of COC using this therapy is less common, especially when two stages are adopted, but recently it has gained visibility, demonstrating a high rate of effectiveness (Souza et al., 2011, Seintou et al., 2014, Masuda et al., 2015, Kim et al., 2016).

The aim was to confirm the effectiveness of the treatment in two stages, by using a tubular surgical decompression device, in order to prevent a pathological fracture of a COC associated with a lower second molar in the left basilar region of the mandible.

\section{Report of Case}

Female patient, 29 years old, with no history of systemic comorbidities, was referred to the Buccomaxillofacial Surgery and Traumatology service at Hospital Universitário Oswaldo Cruz, Recife, Brazil, after discovering a mandibular cystic lesion on routine panoramic radiography. 
The extraoral physical examination showed discreet bone bulging in the left region of the mandibular body, which was palpable, with an evolution time of approximately one year. Regarding the intraoral aspect, no changes were presented. Upon image examination, a well-defined unilocular radiolucent image associated with the crown of the lower left second molar was found in the left posterior basilar region of mandible, with consequent displacement of the second and third lower left molars and root resorption of the lower first molar (Figure 1A). Dentigerous cyst, keratocyst and calcifying odontogenic cyst were included in the differential diagnosis.

Figure 1. Panoramic radiograph. A: Preoperative. Well-defined radiolucent image in the left posterior basilar region of mandible, associated with the crown of the lower left second molar, with consequent displacement of the second and third lower left molars and root resorption of the lower first molar; B: After decompression procedure. Regression of the cystic lesion and distancing of the lower left second molar from the mandibular base; C: Thirty months after the second stage of treatment, excision of the lesion and removal of dental elements. Preservation of the jaw line and bone neoformation.

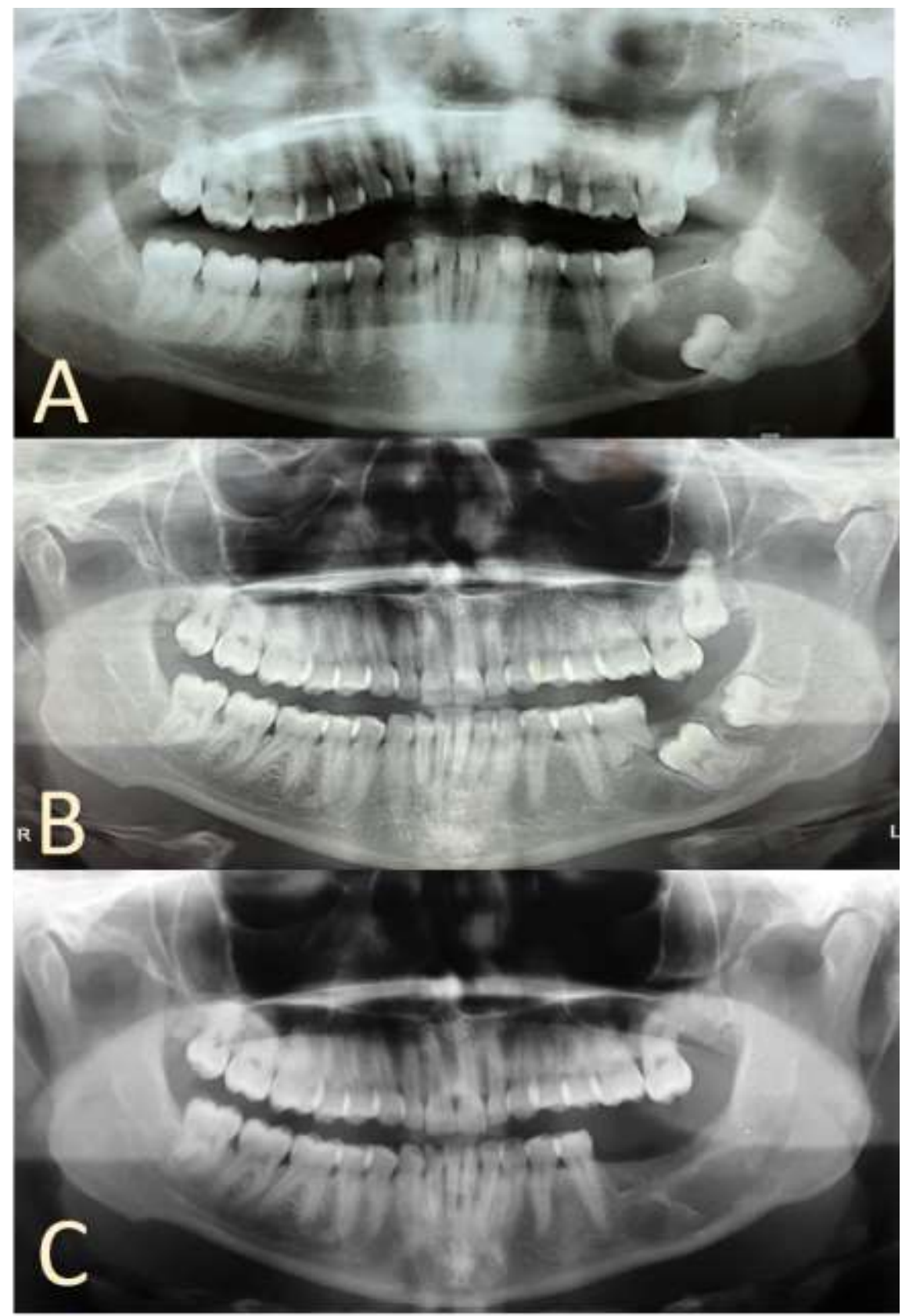


The treatment happened in two stages, under general anesthesia, during the first, was performed an aspiration puncture of brownish liquid (Figure 2A)., incisional biopsy, guiding the material for histopathological analysis (Figure 2B) and device installation for decompression of the lesion (Figure 2C). Part of a tube component of a Foley catheter was used to make the decompression device. This device was sutured with 4-0 nylon to the buccal mucosa. The patient was instructed to irrigate the drain with $0.9 \%$ Saline through the decompression tube twice a day, with monthly clinical follow-up.

Figure 2: First surgical stage. A: Aspiration puncture of brownish liquid; B: Incisional biopsy, guiding the material for histopathological analysis; C: Device installation for decompression.

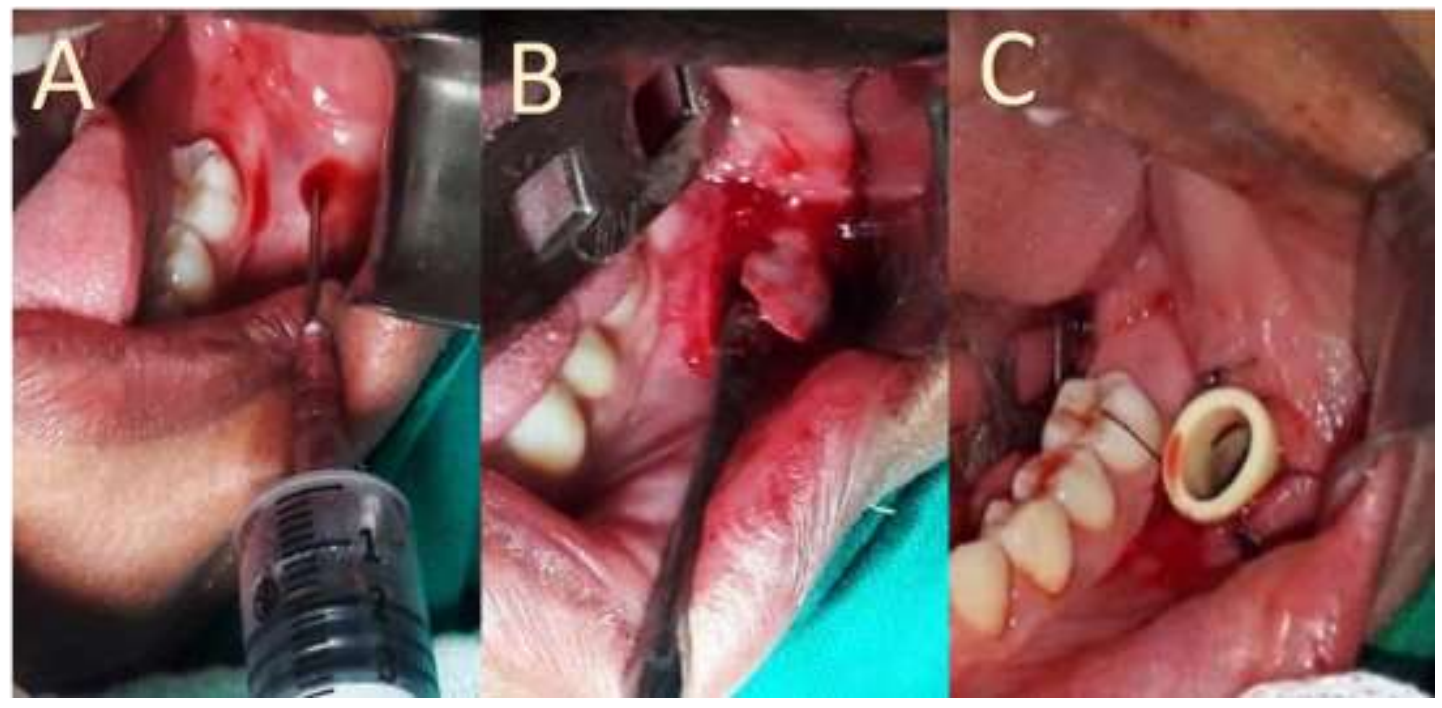

Source: Authors.

By means of the histopathological examination, odontogenic cystic lesion was observed, with calcified foci in cystic coating. Thus, it is confirmed of the diagnosis hypotheses, calcifying odontogenic cyst (Figure 3).

Figure 3. Photomicrograph - Hematoxylin and Eosin stain. A: Cystic odontogenic epithelium (large arrow, magnification, 10). B: Cyst lining and dystrophic calcification (arrow, staining, 40).

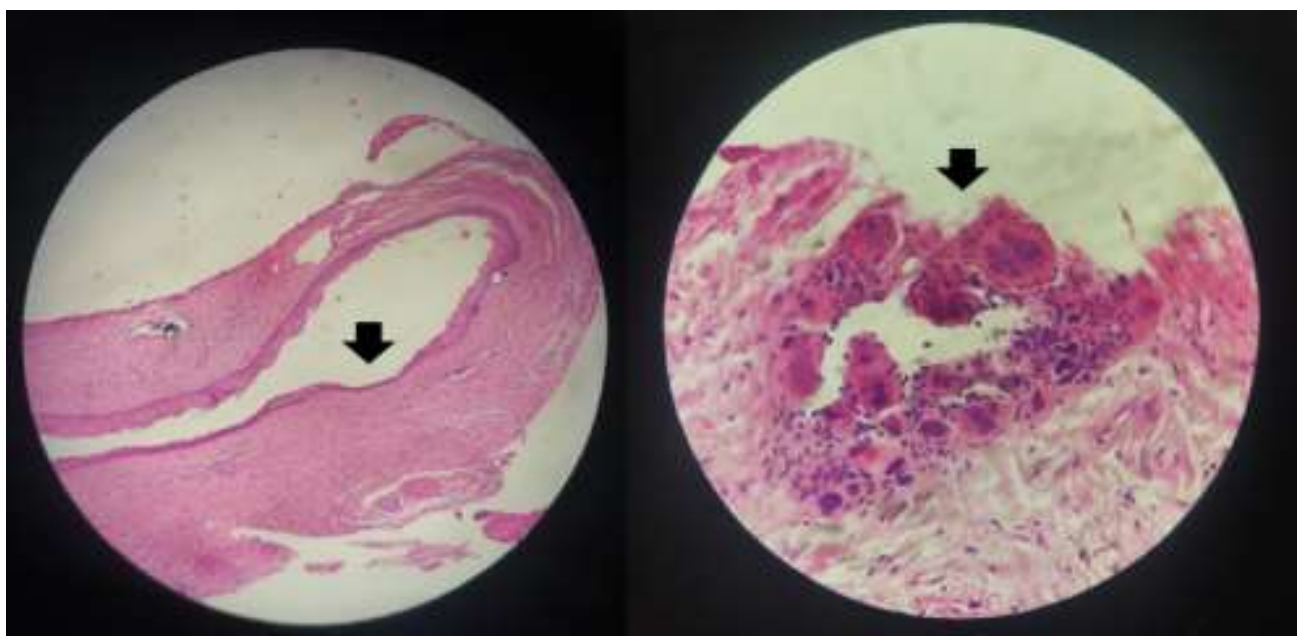

Source: Authors. 
Twenty months after of the initial procedure, was satisfactory regression of the cystic lesion and distancing of the lower left second molar from the mandibular base (Figure 1B), the second surgical step was performed with extraction of the first, second and third lower left molars, enucleation and curettage of the remaining lesion A second histopathological examination confirmed the diagnosis of calcifying odontogenic cyst.

The patient keeps on postoperative follow-up of 30 months, showing no evidence of recurrence of the lesion, with bone neoformation evident in the region (Figure 1C).

\section{Discussion}

The nature of the calcifying odontogenic cyst, cystic or tumor, raises divergences since its identification (Gorlin et al., 1962, Buchener, 1991, Pogrel et al., 2004). The classification as a tumor lesion was established by the WHO in 1992 and recently, in 2017, it was defined as a lesion of a cystic nature by the same association (El-Nagar et al., 2017). However, the understanding of this lesion as a single entity is controversial, since there are several classifications (Praetorius et al., 2005). Four histological variants are described: $\mathrm{COC}$ of a simple cystic nature (type 1), COC associated with odontoma (type 2), COC associated with ameloblastomatous proliferations (type 3) and COC associated with benign odontogenic tumors other than odontoma (type 4) (Ledesma-Montes et al., 2008). The type 1 was found in the case presented here.

The definition of the nature of this pathology is significant since it helps to guide your treatment. Lesions of a "cystic" nature has a so-called conservative surgical approach, whereas lesions defined as tumoral, associated with a locally destructive process, are approached more aggressively (Neville et al., 2016, Emam et al., 2017). In addition to the histological characteristics, clinical features should also be taken into account in their elucidation and treatment (Hong et al., 1991, Ledesma-Montes et al., 2008).

The recommended treatment for COC in general is total excision in one step (Gorlin et al., 1962, Hong et al., 1991). Enucleation associated with curettage is the usual therapy when referring to the cystic variant. So, after removing the lesion, a layer of 1 to $2 \mathrm{~mm}$ of bone must be removed at the periphery of the cystic cavity (Daniels et al., 2004, Souza et al., 2011). A more aggressive therapy is required when the solid COC variant is present (Brondum et al., 1991). However, successful approaches using two steps through decompression or marsupialization and posteriorly enucleation of the lesion have been reported (Souza et al., 2011, Seintou et al., 2014, Masuda et al., 2015, Kim et al., 2016).

Decompression acts efficiently due to pressure reduction in the internal walls of the cystic lesion, which also promotes its reduction (Pogrel et al., 2004). Large injuries may benefit from this therapy, avoiding mutilations and improving patients' quality of life (Monteiro et al., 2018).

It's necessary to pay attention to the differences between decompression using external devices and marsuapialization. Decompression is said to be a technique performed through an opening in the cystic cavity maintained by an object in order to relieve pressure within the cyst (Pogrel, 2003).

We are aware of numerous devices used for this decompression, dropper, pacifier tip, foley catheter. Marsupialization term refers to a technique inner lumen of the cystic is connected to the oral cavity through a suture in the oral mucosa, so there is the conversion of the cyst in a purse (Pogrel, 2003, Allon et al., 2015).

In the case presented, a conservative therapeutic modality was used, with a two-step approach, through decompression of the cystic cavity using a tubular device in the first stage and then enucleation and removal of the lower left molars. Once the pathology has achieved considerable proportions, reaching the mandibular bone basilar and in proximity to the lower left alveolar vascular-nervous bundle, there was a consequent risk of pathological fracture, in addition to injury to the mentioned nerve and transoperative bleeding involved, for the treatment in a single stage. Besides, due to the presence of the lower left second molar involved in the lesion, its removal being necessary, it was positioned under the mandibular base, so that its removal in the first 
stage, in addition to contributing to the risk of pathological fracture, would be almost impossible intraorally, requiring extraoral access, so an aesthetic sequel could be caused by the scar from this access.

The two-stage approach allowed bone deposition, decompression of the cystic cavity, with a substantial regression in size, furthermore, that associated with negative pressure in the region allowed the dental element directly involved in the lesion execute a distancing movement from the jaw base to the alveolar ridge, facilitating its removal by intraoral acess.

Procedures in order to decompress cystic lesions have been used over the years, and is well established for the treatment of other odontogenic cystic lesions, in order to minimize the cyst size, reduce damage and / or sequels caused by surgical extension (Martínez -Pérez et al., 2001, Pogrel et al., 2004, Seintou et al., 2014). This is not a usual therapy for the COC, but has gained visibility with high effectiveness (Souza et al., 2011, Seintou et al., 2014, Masuda et al., 2015, Kim et al., 2016).

However, the total regression of the lesion may take years, the patient's collaboration related to irrigation with saline solution can be difficult, the patient can complain about a bad odor, in addition, close monitoring is necessary (Nakamura et al., 1995). Follow-up after the surgical procedure should be based on clinical and imaging findings, this is necessary since in response to the procedure may be an excessive proliferation of the lining epithelium (Gorlin et al., 1962, Nakamura et al., 1995), besides that, may be a change in the pathology behavior, an injury expansive can become invasive (Nakamura et al., 1995).

After performing the second biopsy in our patient, the diagnosis was confirmed. There was no evidence of recurrence during the 30-month follow-up in our patient. A recurrence is reported in the literature after 1-8 years, so an additional monitoring should be performed (Buchener, 1991).

\section{Conclusion}

The calcifying odontogenic cyst is a rare lesion, but of great importance due to its clinical and functional repercussions. The therapeutic modality adopted must take into account, in addition to the histological evidence, the biological behavior, the anatomical location and the possible surgical complications involved. Decompression, whether performed by devices or by marsupialization, has proven an excellent alternative in the treatment of these injuries, allowing regression before definitive treatment, eliminating recurrence costs and promoting bone preservation. The present case showed the applicability of the twostep approach, by the initial surgical decompression, in the management of a COC, in preventing the occurrence of a pathological fracture.

\section{References}

Allon, D. M., Allon, I., Anavi, Y., Kaplan, I., \& Chaushu, G. (2015). Decompression as a treatment of odontogenic cystic lesions in children. Journal of Oral and Maxillofacial Surgery, 73(4), 649-654.

Brøndum, N., \& Jensen, V. J. (1991). Recurrence of keratocysts and decompression treatment: a long-term follow-up of forty-four cases. Oral surgery, oral medicine, oral pathology, 72(3), 265-269.

Buchner, A. (1991). The central (intraosseous) calcifying odontogenic cyst: an analysis of 215 cases. Journal of oral and maxillofacial surgery, 49(4), 330-339.

Daniels, J. S. M. (2004). Recurrent calcifying odontogenic cyst involving the maxillary sinus. Oral Surgery, Oral Medicine, Oral Pathology, Oral Radiology, and Endodontology, 98(6), 660-664.

De Arruda, J. A. A., Monteiro, J. L. G. C., Abreu, L. G., de Oliveira Silva, L. V., Schuch, L. F., de Noronha, M. S., \& Mesquita, R. A. (2018). Calcifying odontogenic cyst, dentinogenic ghost cell tumor, and ghost cell odontogenic carcinoma: A systematic review. Journal of Oral Pathology \& Medicine, 47(8), $721-730$.

El-Nagar, A. K., Chan, J. K. C., Grandis, J. R., Takata, T., \& Slootweg, P. J. (2017) World Health Organization Classification of Head and Neck Tumours. (4th. ed.), Lyon: IARC Press.

Emam, H. A., Smith, J., Briody, A., \& Jatana, C. A. (2017). Tube decompression for staged treatment of a calcifying odontogenic cyst-A case report. Journal of Oral and Maxillofacial Surgery, 75(9), 1915-1920.

Gorlin, R. J., Pindborg, J. J., Clausen, F. P., \& Vickers, R. A. (1962). The calcifying odontogenic cyst-a possible analogue of the cutaneous calcifying epithelioma of Malherbe: an analysis of fifteen cases. Oral Surgery, Oral Medicine, Oral Pathology, 15(10), 1235-1243. 
Hong, S. P., Ellis, G. L., \& Hartman, K. S. (1991). Calcifying odontogenic cyst: a review of ninety-two cases with reevaluation of their nature as cysts or neoplasms, the nature of ghost cells, and subclassification. Oral surgery, oral medicine, oral pathology, 72(1), 56-64.

Jaeger, F., de Noronha, M. S., Silva, M. L. V., Amaral, M. B. F., Grossmann, S. D. M. C., Horta, M. C. R., ,.. \& Mesquita, R. A. (2017). Prevalence profile of odontogenic cysts and tumors on Brazilian sample after the reclassification of odontogenic keratocyst. Journal of Cranio-Maxillofacial Surgery, 45(2), 267-270.

Johnson III, A., Fletcher, M., Gold, L., \& Chen, S. Y. (1997). Calcifying odontogenic cyst: a clinicopathologic study of 57 cases with immunohistochemical evaluation for cytokeratin. Journal of oral and maxillofacial surgery, 55(7), 679-683.

Kim, Y., Choi, B. E., \& Ko, S. O. (2016). Conservative approach to recurrent calcifying cystic odontogenic tumor occupying the maxillary sinus: a case report. Journal of the Korean Association of Oral and Maxillofacial Surgeons, 42(5), 315-320.

Ledesma-Montes, C., Gorlin, R. J., Shear, M., Prae Torius, F., Mosqueda-Taylor, A., Altini, M., ... \& Meneses-García, A. (2008). International collaborative study on ghost cell odontogenic tumours: calcifying cystic odontogenic tumour, dentinogenic ghost cell tumour and ghost cell odontogenic carcinoma. Journal of oral pathology \& medicine, 37(5), 302-308.

Martínez-Pérez, D., \& Varela-Morales, M. (2001). Conservative treatment of dentigerous cysts in children: a report of 4 cases. Journal of oral and maxillofacial surgery, 59(3), 331-333.

Masuda, K., Kawano, S., Yamaza, H., Sakamoto, T., Kiyoshima, T., Nakamura, S., \& Nonaka, K. (2015). Complete resolution of a calcifying cystic odontogenic tumor with physiological eruption of a dislocated permanent tooth after marsupialization in a child with a mixed dentition: a case report. World journal of surgical oncology, 13(1), 1-4.

Monteiro, J. L. G. C., de Arruda, J. A. A., \& do Egito Vasconcelos, B. C. (2018). Tube Decompression for Staged Treatment of a Calcifying Odontogenic Cyst. Journal of Oral and Maxillofacial Surgery, 76(4), 683.

Nakamura, N., Higuchi, Y., Tashiro, H., \& Ohishi, M. (1995). Marsupialization of cystic ameloblastoma: a clinical and histopathologic study of the growth characteristics before and after marsupialization. Journal of oral and maxillofacial surgery, 53(7), 748-754.

Neville B, Damm D, Allen C, et al (2016). Oral and Maxillofacial Pathology (4 ${ }^{\text {th }}$ ed). Elsevier Health Sciences.

Praetorius, F. (2005). Calcifying cystic odontogenic tumor. World Health Organization Classification of Tumours: Pathology and genetics of tumours of the head and neck, 313 .

Pogrel, M. A., \& Jordan, R. C. K. (2004). Marsupialization as a definitive treatment for the odontogenic keratocyst. Journal of oral and maxillofacial surgery, 62(6), 651-655.

Pogrel, M. A. (2003). Decompression and marsupialization as a treatment for the odontogenic keratocyst. Oral and Maxillofacial Surgery Clinics, 15(3), 415427.

Seintou, A., Martinelli-Kläy, C. P., \& Lombardi, T. (2014). Unicystic ameloblastoma in children: systematic review of clinicopathological features and treatment outcomes. International Journal of Oral and Maxillofacial Surgery, 43(4), 405-412.

Souza, L. N., Souza, A. C. R. A., Gomes, C. C., Loyola, A. M., Durighetto, A. F., Gomez, R. S., \& Castro, W. H. (2007). Conservative treatment of calcifying odontogenic cyst: report of 3 cases. Journal of oral and maxillofacial surgery, 65(11), 2353-2356.

Toida, M. (1998). So-called calcifying odontogenic cyst: review and discussion on the terminology and classification. Journal of oral pathology \& medicine, 27(2), 49-52.

Yong, L. U., Mock, D., Takata, T., \& Richard, C. K. J (1999). Odontogenic ghost cell carcinoma offour new cases and review of the literature. Journal of Oral Pathology \& Medicine, 28(7), 323-329.

Yoshiura, K., Tabata, O., Miwa, K., Tanaka, T., Shimizu, M., Higuchi, Y., \& Kanda, S. (1998). Computed tomographic features of calcifying odontogenic cysts. Dentomaxillofacial Radiology, 27(1), 12-16. 